Blockchain, Cryptocurrencies and Distributed Organizations

\author{
Research Article
}

\title{
Opportunities and Challenges of Using Blockchain Technology in Government Accounting in Brazil
}

Paula Raymundo Prux ${ }^{1}$

Fernanda da Silva Momo ${ }^{1}$

Claudia Melati ${ }^{1}$

${ }^{1}$ Universidade Federal do Rio Grande do Sul, Porto Alegre, RS, Brazil.

Received 08 October 2020. This paper was with the authors for one revision. Accepted 13 September 2021.

First published online 20 October 2021.

Editors-in-Chief: Carlo Gabriel Porto Bellini (D) (Universidade Federal da Paraíba, Brazil);

Ivan Lapuente Garrido (D) (Universidade do Vale do Rio dos Sinos, Brazil)

Guest Editors: Jorge Renato Verschoore (iD (Universidade do Vale do Rio dos Sinos, Brazil);

Eduardo Henrique Diniz (iD) (Fundação Getúlio Vargas, EAESP, Brazil);

Ricardo Colomo-Palacios (D) (Østfold University College, Norway)

Reviewers: Two anonymous reviewers

Editorial assistants: Kler Godoy and Simone Rafael (ANPAD, Maringá, PR, Brazil) 


\section{ABSTRACT}

New technologies lead to significant changes in how public and private organizations structure their processes and activities. This study aims to identify the challenges and opportunities of using blockchain technology in government accounting in Brazil. This is a descriptive research using quantitative and qualitative data, collected through a questionnaire applied to a non-probabilistic sample of 94 professionals. The data were submitted to descriptive statistical analysis and content analysis, based on seven categories: technology, government accounting, security, transparency, control, change, and knowledge. For $89.4 \%$ of respondents, blockchain can improve government accounting and be applied to financial transactions, auditing, and asset transfers. The technology offers the benefits of trust and control, information security, and control against fraud and corruption. For $98.9 \%$ of the sample, the challenges of using blockchain technology in government accounting are the lack of knowledge about the technology and its cost-benefit and implementation, difficulties in replacing or adapting systems, and few blockchain use cases demonstrating the technology's use and application.

Keywords: government accounting; blockchain; opportunities; challenges

JEL Code: M4, O3 


\section{INTRODUCTION}

The convergence of administrative procedures and digital technologies in management systems marks the Fourth Industrial Revolution (Industry 4.0) (Schwab, 2016). The speed, reach, and impact of technology affect institutions in all countries, including the field of accounting. Industry 4.0 entails new operations and insights from accountants, who are discussing topics such as disruption, blockchain, compliance, and artificial intelligence (AI) (Rikhardsson \& Yigitbasioglu, 2018). In Brazil, for example, the implementation of the Public Digital Bookkeeping System (SPED) by the country's federal revenue agency (RFB) has advanced the accounting sector. The system allows data cross-checking, integrates the accounting and tax information on taxes levied in different levels of government (federal, state, and local), rationalizes, standardizes, and consolidates accessory obligations, and improves the process of tax inspection (Sebold, Pioner, Schappo, \& Pioner, 2012).

Technology has led to changes in both government and business sectors, offering new management tools to improve access to information and transparency (Chahin, Cunha, Knight, $\&$ Pinto, 2004). It has contributed to accounting processes automation increasing productivity, efficiency, better customer service, information quality, and cost reduction (Ionescu, 2019; Lee \& Tajudeen, 2020). Blockchain technology emerged amidst this context in 2008, characterized as a tool that ensures data reliability and security without the need for a central regulatory authority (Nakamoto, 2008; Tapscott \& Tapscott, 2016). Its core features are encryption and the process of verifying the transactions until their registration, which makes the transaction safe and irreversible (Swan, 2015).

According to Talwar (2015), blockchain technology allows verifying each transaction, which could mean the end of random sampling. Thus, real-time auditing is possible since the transaction data is recorded in the blockchain ledger (Tapscott \& Tapscott, 2016). Blockchain and artificial intelligence can transform fraud investigations and forensic accounting, issue alerts, and investigate unusual transactions as they occur (Talwar, 2015). Therefore, as highlighted by Moura, Brauner, and Janissek-Muniz (2020), the fact that blockchain can offer safe data storage and management contributes to making a case for its adoption in the public sector.

This study recognizes the potential of this technology to improve government accounting and considers the challenges of implementing projects using blockchain - lack of knowledge and use cases, low number of capable institutions and developers, and lack of encouragement from the public sector - as identified by Giongo and Balestro (2019). It proposes advancing the discussion about the use of blockchain technology by exploring the perception of Brazilian professionals working in the government. Thus, the research question guiding this study is: Considering the perspective of experts in technology and accounting in the public sector, what are the main opportunities and challenges of blockchain technology for government accounting?

Therefore, this work identifies the main opportunities and challenges of using blockchain in Brazilian government accounting. It observes the current context where the public sector seeks agility, quality, and accountability to administrative practices by resorting to smart and electronic

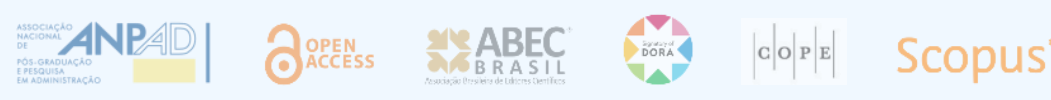


government, using technology to organize public data (Melati \& Janissek-Muniz, 2020). The volume of thousands of daily transactions in the Brazilian Integrated System of Federal Government Financial Administration (SIAFI), to mention only one of the systems in government accounting, is a crucial element in this context, requiring technologies for more transparency and quality of information. This study contributes to identify the perception of public actors about blockchain. The research addresses its potential to promote security in data storage and processing, information traceability, and government transparency (Kossow \& Dykes, 2018), as well as avoiding data duplication, to generate information integrity, and to improve the workflow (Atzori, 2018), building policies that add public value (Scholl \& Bolívar, 2019).

The research uses qualitative and quantitative data collected through a questionnaire with both open and close-ended questions, 19 in total. The non-probabilistic sample was composed of 94 professionals. The closed-ended questions were analyzed with descriptive statistics and the openended questions with content analysis.

This article is organized into five sections, including this introduction. The second section presents the concept of blockchain in the context of government accounting, followed by the methodology. The fourth section shows the results, and the last section offers the final considerations.

\section{BLOCKCHAIN AND GOVERNMENT ACCOUNTING}

The concepts and discussions presented in this section are based on a literature review of the databases BDTD/IBICT (Brazilian digital library of dissertations and theses of the Brazilian Institute of Information in Science and Technology), Periódicos Capes, and Google Scholar. The search was carried out from August 2018 to October 2019, using the keywords 'blockchain,' 'blockchain use cases,' 'blockchain accounting,' and 'blockchain public sector.' The selected literature is briefly presented below, describing the studies' objectives and conclusions.

The definition of blockchain by Wright and Filippi (2015) stands out. They describe it as a "distributed, shared, encrypted-database that serves as an irreversible and incorruptible public repository of information” (Wright \& Filippi, 2015, p. 2.) The essence of this technology is how information is recorded. Each transaction originates a unique cryptographic key, created based on a code verification and validation network, which guarantees a safe transaction (Swan, 2015). The technical characteristics of this technology allow the expansion of information attributes such as data integrity and reliability and the establishment of validation mechanisms to reduce fraud and make accountability more precise and accessible (Nofer, Gomber, Hinz, \& Schiereck, 2017; Zachariadis, Hileman, \& Scott, 2019).

Blockchain can be structured into two major groups: public (permissionless) or private (permissioned) networks. Public networks have their own rules, and their operation does not depend on legal or regulatory aspects, while private networks are restricted to corporations - in this case, the blockchain network follows a specific regulation of pre-selected actors to participate

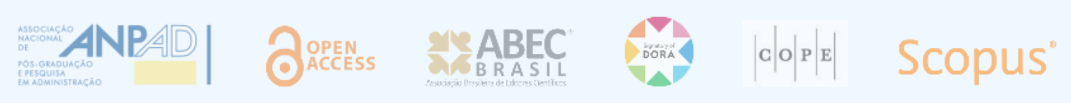


(Formigoni, Braga, \& Leal, 2017; Yermack, 2017). Thus, the cryptographic access keys for a blockchain categorize it as being a public or private network, since the wide access and anonymous keys are related to public networks, while the controlled keys (requesting permission for the registration of transactions) are related to the private blockchain network (Darlington, 2021).

Regardless of how blockchain is technologically structured, the application opportunities and its potential to redesign transactions and processes in business are outstanding (Cohen, Amorós, \& Lundy, 2017; Swan, 2015). Blockchain can be used (beyond its application in cryptocurrency) to create smart contracts, register a variety of assets (stocks, real estate, vehicles, luxury handbags, works of art), and even "for public records such as real estate titles, birth certificates, driver's licenses, and university degrees" (Yermarck, 2017, p. 8). Therefore, blockchain is considered the new internet of business since its potential decentralization can affect the application of laws or their implementation and the governments, organizations, and society in general in their way of operating (Atzori, 2015; Wright \& Filippi, 2015).

Giongo and Balestro (2019) approached the main characteristics of blockchain technology, addressing its impacts on accounting and finance. After carrying out exploratory research and interviewing three professionals, the authors observed that it was not yet possible to measure the scope of the technology. However, they concluded that blockchain potentially affects several areas, including finance and accounting, and stressed its application in the banking sector and its short-term impacts in auditing. Migliorini and Rocha (2019) researched how blockchain can be used within the accounting system, the level of acceptance of accounting professionals in the face of new technologies, and their perception regarding blockchain. Counting on a sample of 526 participants, the authors concluded that accounting professionals still have little knowledge about blockchain and cannot foresee the use of this technology in the field.

Biancolini, Silva, and Osti (2018) analyzed the possible uses of blockchain in public administration, mentioning several cases and pointing out positive and negative aspects. According to the authors, the technology is disruptive and can be widely used in the public sector, particularly in the areas of tax and compliance, increasing transparency, and reducing transaction costs. Bastos, Andujar, and Rode (2018) sought to identify the main impacts of blockchain as a tool for auditing, exploring its advantages and disadvantages in the face of future challenges regarding auditing practices. Based on systematic bibliographic research, the authors noticed an increase in the number of financial institutions using blockchain. Bastos et al. (2018) concluded that the characteristics of blockchain allow the implementation of continuous internal and external audits. They also point out a lack of regulation and legal environment in many countries. Dai and Vasarhelyi (2017) researched blockchain applications in accounting in order to discuss how this technology can support a real-time, verifiable, and transparent accounting ecosystem. The authors propose that blockchain is a tool to authenticate auditing information. They suggest conducting more research on the technology's applications and challenges in specific areas such as government auditing.

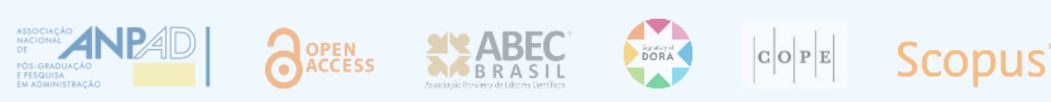


There is a positive and constructive relationship between the use of blockchain and the public sector. This technology affects the social, productive, and organizational dynamics through new tools created to solve contemporary problems. Most blockchain applications in the public sector are related to data processing and security, new models of state regulation, and new institutional procedures (Moura, Brauner, \& Janissek-Muniz, 2020). In this sense, applying this technology in the public sector makes it possible to develop governance models based on shared data and distributed systems that allow, for example, more flexible government regulatory agencies and more transparent consortia (Colchester, 2019).

Although there is an optimistic perspective in the public sector considering the technology's potential to change society, Atzori (2015) emphasizes weighing the risks and benefits of possible applications as a disruptive technology for governments, avoiding utopian expectations or technocratic reasoning traps.

The search for blockchain use cases resulted in experiences carried out in the government and business sectors. Table 1 summarizes the literature findings on the technology's challenges and opportunities.

Table 1

\section{Use cases of blockchain in accounting}

\begin{tabular}{|c|c|c|c|c|}
\hline Use cases & Applications & Opportunities & Challenges & References \\
\hline $\begin{array}{l}\text { Continuous } \\
\text { auditing }\end{array}$ & $\begin{array}{l}\text { Financial transactions } \\
\text { available in real-time }\end{array}$ & $\begin{array}{l}\text { More accurate and } \\
\text { transparent corporate } \\
\text { reporting }\end{array}$ & $\begin{array}{l}\text { Regulatory } \\
\text { environment }\end{array}$ & $\begin{array}{l}\text { Bastos et al. } \\
\text { (2018); Dai and } \\
\text { Vasarhelyi } \\
\text { (2017) }\end{array}$ \\
\hline $\begin{array}{l}\text { Junta Comercial do } \\
\text { Estado do Ceará } \\
\text { (Commercial } \\
\text { Registry Office of } \\
\text { the State of Ceará } \\
\text { - Brazil) }\end{array}$ & $\begin{array}{l}\text { Protection of the } \\
\text { registered companies' } \\
\text { databases; combating } \\
\text { fraud }\end{array}$ & $\begin{array}{l}\text { Less time spent } \\
\text { validating; security, } \\
\text { trust, and registry } \\
\text { immutability }\end{array}$ & $\begin{array}{l}\text { Extending the } \\
\text { process to a larger } \\
\text { scope }\end{array}$ & $\begin{array}{c}\text { Biancolini et al. } \\
(2018)\end{array}$ \\
\hline $\begin{array}{l}\text { Rede Blockchain } \\
\text { do Sistema } \\
\text { Financeiro } \\
\text { Nacional } \\
\text { (Brazilian National } \\
\text { Financial System's } \\
\text { Blockchain } \\
\text { Network) }\end{array}$ & $\begin{array}{l}\text { Protection and sharing } \\
\text { data among banks; } \\
\text { combating fraud }\end{array}$ & $\begin{array}{c}\text { Safe and fast } \\
\text { transactions; instant } \\
\text { payments }\end{array}$ & $\begin{array}{l}\text { High volume of } \\
\text { transactions in } \\
\text { peak hours }\end{array}$ & $\begin{array}{l}\text { Pimenta and } \\
\text { Seco (2019) }\end{array}$ \\
\hline $\begin{array}{l}\text { PIER - Plataforma } \\
\text { de integração de } \\
\text { informaçoses das } \\
\text { entidades } \\
\text { reguladoras } \\
\text { (Platform to } \\
\text { Integrate } \\
\text { Information of } \\
\text { Regulatory } \\
\text { Agencies) }\end{array}$ & $\begin{array}{l}\text { Platform of joint and } \\
\text { distributed control of } \\
\text { market information; real- } \\
\text { time interaction }\end{array}$ & $\begin{array}{l}\text { Increase of regulatory } \\
\text { transparency; safe and } \\
\text { auditable process; } \\
\text { reduction in control } \\
\text { failures }\end{array}$ & $\begin{array}{l}\text { Expanding the } \\
\text { platform to the rest } \\
\text { of the Brazilian } \\
\text { public sector }\end{array}$ & $\begin{array}{l}\text { Pimenta and } \\
\text { Seco (2019) }\end{array}$ \\
\hline
\end{tabular}

Continues

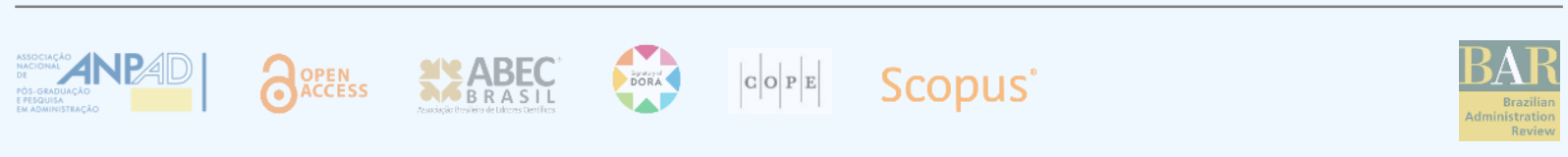


Table 1 (Continued)

\begin{tabular}{|c|c|c|c|c|}
\hline Use cases & Applications & Opportunities & Challenges & References \\
\hline $\begin{array}{l}\text { Sistema Financeiro } \\
\text { Digital (SFD) } \\
\text { (Brazilian Digital } \\
\text { Financial System) }\end{array}$ & $\begin{array}{l}\text { Connection of banking } \\
\text { datacenters; real-time } \\
\text { transactions ( } 24 \text { hours) }\end{array}$ & $\begin{array}{l}\text { Increase in security } \\
\text { and ease in banking } \\
\text { transactions }\end{array}$ & $\begin{array}{l}\text { Cultural change to } \\
\text { models without } \\
\text { intermediaries }\end{array}$ & $\begin{array}{c}\text { Biancolini et al. } \\
\text { (2018) }\end{array}$ \\
\hline $\begin{array}{l}\text { Solução Online de } \\
\text { Licitação (Online } \\
\text { Solution for Public } \\
\text { Procurement) }\end{array}$ & $\begin{array}{l}\text { Transparency in public } \\
\text { purchases from } \\
\text { cooperatives and } \\
\text { membership } \\
\text { organizations - Bahia } \\
\text { Produtiva project }\end{array}$ & $\begin{array}{l}\text { Automatic generation } \\
\text { of invitations to bid, } \\
\text { minutes, and } \\
\text { contracts, based on } \\
\text { stored data; online } \\
\text { monitoring of bidding } \\
\text { results }\end{array}$ & $\begin{array}{l}\text { Bring technology } \\
\text { closer to } \\
\text { cooperatives and } \\
\text { membership } \\
\text { organizations; } \\
\text { centralize purchase } \\
\text { of goods and } \\
\text { services in the app }\end{array}$ & $\begin{array}{c}\text { Biancolini et al. } \\
\text { (2018) }\end{array}$ \\
\hline $\begin{array}{l}\text { SERPRO } \\
\text { Blockchain } \\
\text { Platform }\end{array}$ & $\begin{array}{l}\text { Transactions of the } \\
\text { Tesouro Direto } \\
\text { (program of the } \\
\text { Brazilian government to } \\
\text { sell government bonds) }\end{array}$ & $\begin{array}{l}\text { Easy investor } \\
\text { registration and } \\
\text { access }\end{array}$ & $\begin{array}{l}\text { Increase investors' } \\
\text { base }\end{array}$ & Brasil (2017) \\
\hline $\begin{array}{c}\text { Santander One Pay } \\
\text { FX }\end{array}$ & $\begin{array}{l}\text { International transfers } \\
\text { for individuals }\end{array}$ & $\begin{array}{l}\text { Speed in transfers; } \\
\text { reduction of term and } \\
\text { fees for foreign } \\
\text { exchange remittances }\end{array}$ & $\begin{array}{l}\text { Include other } \\
\text { banking services } \\
\text { and expansion to } \\
\text { other countries }\end{array}$ & $\begin{array}{c}\text { Biancolini et al. } \\
\text { (2018); Giongo } \\
\text { and Balestro } \\
\text { (2019) }\end{array}$ \\
\hline TruBudget BNDES & $\begin{array}{l}\text { Tracking money; } \\
\text { sharing financial } \\
\text { information among } \\
\text { institutions }\end{array}$ & $\begin{array}{l}\text { Increase transparency } \\
\text { in public budget } \\
\text { allocation; } \\
\text { circularization in } \\
\text { auditing }\end{array}$ & $\begin{array}{l}\text { Scale the scope to } \\
\text { cover all projects of } \\
\text { the Amazon Fund } \\
\text { that are in the } \\
\text { disbursement } \\
\text { stage }\end{array}$ & $\begin{array}{c}\text { Arantes, } \\
\text { D'Almeida, } \\
\text { Onodera, } \\
\text { Moreno and } \\
\text { Almeida (2018) }\end{array}$ \\
\hline BNDES Token & $\begin{array}{l}\text { Tracking public funds } \\
\text { used to finance public } \\
\text { agencies or operations } \\
\text { using non-refundable } \\
\text { grants }\end{array}$ & $\begin{array}{l}\text { More control; } \\
\text { facilitates monitoring } \\
\text { operations }\end{array}$ & $\begin{array}{l}\text { Expanding to new } \\
\text { use cases such as } \\
\text { automatic tax } \\
\text { collection }\end{array}$ & $\begin{array}{c}\text { Arantes et al. } \\
\text { (2018); Giongo } \\
\text { and Balestro } \\
\text { (2019) }\end{array}$ \\
\hline
\end{tabular}

Note. Source: Elaborated by the authors.

The use cases include continuous auditing, public procurement, tracking public funds, sharing financial data, companies' public registration, asset transfers, and banking transactions. Financial institutions, especially banks, concentrate the largest number of use cases. As for the opportunities to apply the technology in government accounting, the literature examined revealed the use of blockchain in auditing, budgetary and financial management, public procurement, contracts, accounting and budgetary records, financial transactions, and asset transfers. The use cases demonstrated possible benefits, such as transparency, quality, security, and validation of data and information, as well as a control against fraud. The challenges observed are linked to regulation, scalability, performance, and cultural change, particularly related to the lack of use cases.

Although the study is based on an analysis of Brazilian accounting, it is worth mentioning that blockchain technology is being used to facilitate various processes worldwide. Examples studied in academic research are the health platform of Estonia and the Dubai Blockchain Strategy, which enable financial transactions through blockchain (Alcantara, Rodrigues, Lima, \& Nunes, 2019). Other cases are the new model of land ownership record in India (Thakur, Doja, Dwivedi, Ahmad, \& Khadanga, 2019), the system to track products imported from abroad into China,

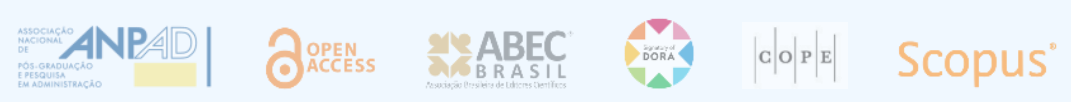


and online voting for public policy projects and accessible voting systems in Australia (Xu, Weber, $\&$ Staples, 2019). These examples reinforce the importance of continuing and deepening the academic research on blockchain technology and its numerous opportunities.

Based on the conceptual analysis and considering the objective of identifying forms of using blockchain technology and the challenges of applying it in public accounting, the following section presents the methodological path used in this research.

\section{METHODOLOGY}

This descriptive research (Gil, 2008) analyzes and describes blockchain characteristics in government accounting, seeking relationships between the variables involved. It uses quantitative and qualitative data in an attempt to comprehend the perceptions of experts regarding the use of the technology in government accounting. The data was collected through a questionnaire created on the Google Docs platform, with questions based on the literature. The questionnaire contained six identification questions (gender, age, workplace, occupation, education background, and level of education); two questions to assess the participant's knowledge on blockchain; one question about potential benefits (closed-ended question, using a five-point scale); one question about the application of blockchain in activities of government accounting (using a five-point scale); two questions about the challenges of using the technology; three questions about blockchain applicability and adoption; one on whether blockchain could improve government accounting (open-ended question, where the participant had to justify the answer); two open-ended questions about opportunities and challenges of using blockchain in government accounting.

After a thorough literature review focused on the studies by Migliorini and Rocha (2019) and Aquino (2019), and from the analysis of the researched use cases, it was possible to identify categories of blockchain technology for the context of Brazilian public accounting. Such categories guided the development of the research questionnaire and, later, the discussion of results.

With the definition of the research categories, it was possible to elaborate a first questionnaire, applied with four specialists for validation: (a) the civil servant, with a master in regional development; (b) a government accountant, with a specialization in accounting; (c) a civil servant, $\mathrm{PhD}$ student in public policy; and (d) an expert, $\mathrm{PhD}$ in administration in the area of systems and technology management. The first three specialists worked in the Secretariat of Planning, Budget, and Management of the state of Rio Grande do Sul. The other specialist was a professor at a federal university in southern Brazil. The responses led to changes in the order of questions, improvements in the technical language used in public accounting and technology, and the text was modified to facilitate understanding. Also, some questions were suppressed, and others included to meet the research objectives.

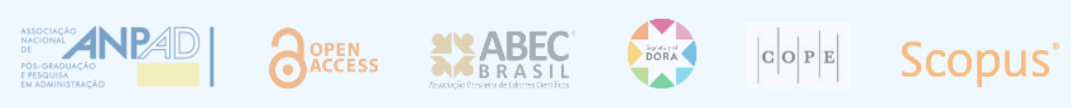


The questionnaires were sent via email and WhatsApp to potential participants in September 2019. These professionals were contacted using data from institutional websites of state-owned companies, and local, state, and federal agencies, seeking to cover various accounting segments and behavioral profiles. Although the search was conducted on institutional sites of Brazilian public agencies at the federal, state, and local levels of government, most agencies examined were from the state of Rio Grande do Sul, given the proximity to the researchers. In Rio Grande do Sul, the agencies analyzed more extensively were the state bank, the State Court of Accounts, and the Federal University of Rio Grande Sul. As for other Brazilian agencies, the Ministry of Planning and Economy and the Federal Court of Accounts stood out.

A total of 763 emails were sent, and the message introducing the questionnaire asked the recipients to share it with other people. The responses were collected from September 9 to October 21, 2019. A non-probabilistic sample of 94 specialists was obtained, with male respondents counting $76.6 \%$ of the results and female respondents $23.4 \%$. About the age group, the highest concentration was 31 to 40 years old, with $40.4 \%$ (38 respondents), $28.7 \%$ were between 41 and 50 years old ( 27 respondents), 18.1\% (17 respondents) were between 51 and 71 years old, and $12.8 \%$ (12 respondents) were between 20 and 30 years old. It is worth highlighting that, as expected, the majority of participants worked in the public sector, as shown in Table 2 below:

Table 2

\section{Sector respondents work in}

\begin{tabular}{lcc}
\hline \multicolumn{1}{c}{ Sector of activity } & Number of respondents & Percentage \\
\hline Self-employment & 1 & 1.1 \\
Accounting association & 1 & 1.1 \\
Private sector & 13 & 13.8 \\
Public sector & 79 & 84.0 \\
\hline
\end{tabular}

Note. Source: Elaborated by the authors.

As for the field of training, accounting sciences and information and communication technology stood out, with $37.2 \%$ and $24.5 \%$ (35 and 23 respondents), respectively. There were also respondents trained in the field of administration and law. As for the level of education, the majority of participants are well qualified, as shown in Table 3 below:

Table 3

Respondents' education

\begin{tabular}{lcc}
\hline \multicolumn{1}{c}{ Level of education } & Number of respondents & Percentage \\
\hline Degree & 20 & 21.3 \\
Post-degree specialization & 46 & 48.9 \\
Master & 22 & 23.4 \\
PhD & 6 & 6.40 \\
\hline
\end{tabular}

Note. Source: Elaborated by the authors.

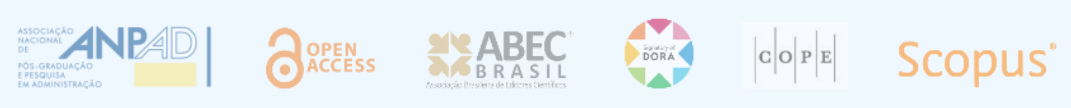


Table 4 shows the public agencies where respondents employed in the public sector work. The majority of respondents (84\%) declared to work in the public sector.

Table 4

Public agencies respondents work in

\begin{tabular}{lcc}
\hline \multicolumn{1}{c}{ Public sector's department/agency } & $\begin{array}{c}\text { Number of } \\
\text { respondents }\end{array}$ & Percentage \\
\hline $\begin{array}{l}\text { Secretariat of Planning, Budget, and Management of the state of Rio Grande do } \\
\text { Sul }\end{array}$ & 11 & 14.0 \\
Secretariat of Finance of the state of Rio Grande do Sul & 7 & 8.9 \\
Executive branch of the Federal District & 16 & 20.2 \\
Executive branch of the states of Pernambuco, Paraná, São Paulo, and Alagoas & 13 & 16.4 \\
Other public agencies & 32 & 40.5 \\
\hline
\end{tabular}

Note. Source: Elaborated by the authors.

The participants working in 'other public agencies' (Table 3) are employed in agencies such as the Central Bank of Brazil, Bank of the State of Rio Grande do Sul (Banrisul), Brazilian Development Bank (BNDES), National Institute of Information Technology, GNova Laboratory of Innovation of the National School of Administration (ENAP), State Court of Audit of Rio Grande do Sul (TCE), Rio Grande do Sul Court of Justice (TJRS), Rio Grande do Sul Regional Accounting Council (CRCRS), Municipality of Porto Alegre (in Rio Grande do Sul), and Municipality of Monte Alto (in the state of São Paulo).

The analysis was developed based on data appreciation, tabulation, organization, and categorization, considering the frequency of words using the MAXQDA software. After, the data was submitted to scientific tests to obtain evidence, and statistical analyzes were performed through descriptive statistics and data-crossings. The open-ended questions underwent content analysis. The main elements obtained in the analysis will be presented and discussed in the next section.

\section{PRESENTATION AND DISCUSSION OF RESULTS}

This section presents and discusses the main results obtained from the 94 questionnaires responded. The focus is to understand how blockchain technology is applied in public agencies and its potential benefits.

Regarding the knowledge about blockchain and the participants' perspective on its benefits in government accounting, most respondents (40.4\%) stated that they were able to define blockchain and could see its usability, but do not participate in projects involving this technology in their area of work. Therefore, most respondents were familiar with the technology and its usability, even though $17 \%$ of the respondents declared to have heard the term, but were unable

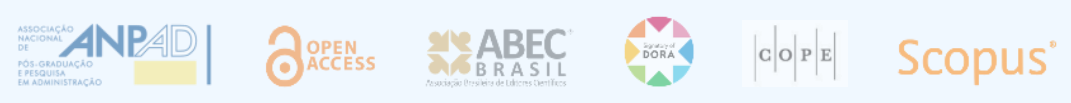


to define it. Among the accountants, $28.6 \%$ said they were able to define blockchain, imagine how it works, but did not participate in projects in the area, while $22.9 \%$ declared to have heard the term but could not offer a definition, and the same percentage could define blockchain but did not see the applicability in government accounting. Among technology professionals, $47.8 \%$ declared to be able to define blockchain and imagine how it works, although not engaged in projects using the technology in their field of work, and only $4.3 \%$ had heard the term but could not offer a definition. It is possible to observe that respondents with an ICT background are more familiar with the concept than other participants.

Thus, the research sample suggests that knowledge about blockchain is already disseminated since many participants knew the concept and were able to offer a definition. However, the number of respondents who claimed to participate in projects involving blockchain in the public sector was very low.

Most respondents reported having obtained information about the topic in journals and newspapers, along with books, interviews, blogs, and technology forums. Some participants mentioned watching documentaries, videos, university and specialist channels, and social media, participating in training events, being informed through conversations in the workplace, discussions with experts on the subject, and studying companies that work with blockchain. As for the opportunities and benefits that may arise from the use of blockchain in government accounting, the close-ended question offered a five-point scale (one $=$ not applicable to five $=$ fully applicable). Table 5 shows that the item trust and control obtained the highest mean, 4.63. Information security obtained 4.55 and control against fraud and corruption, 4.51 .

Table 5

Opportunities and potential benefits of blockchain in government accounting

\begin{tabular}{lc}
\hline \multicolumn{1}{c}{ Opportunities/potential benefits } & Mean \\
\hline Trust and control & 4.63 \\
Information security & 4.55 \\
Control against fraud and corruption & 4.51 \\
Quality of data & 4.20 \\
Freedom of information and transparency & 4.16 \\
Efficiency & 4.13 \\
Governance & 4.07 \\
Data predictive capacity & 3.45 \\
\hline
\end{tabular}

Note. Source: Elaborated by the authors.

The opportunities were marked as fully applicable as follows: trust and control (70.2\%), information security (67\%), and control against fraud and corruption (63.8\%). Governance and data predictive capacity were considered partially applicable by $39.4 \%$ of the participants. These potential benefits are in line with the research by Biancolini et al. (2018). The authors argue that blockchain technology may offer greater control, transparency, and security, facilitating selfprotection and inspection by the population. Regarding the application of blockchain in activities

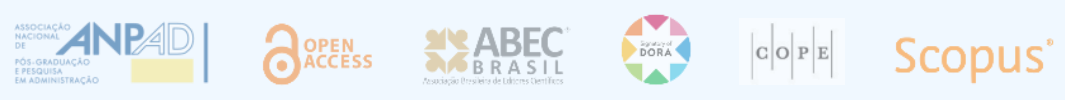


of government accounting, the items with the highest mean were financial transactions (4.65), auditing (4.56), and asset transfer (4.46).

Table 6

Blockchain use in government accounting

\begin{tabular}{ll}
\hline \multicolumn{1}{c}{ Activities } & Mean \\
\hline Financial transactions & 4.65 \\
Auditing & 4.56 \\
Asset transfer & 4.46 \\
Accounting records & 4.35 \\
Compliance & 4.30 \\
Improving tax collection and inspection capacity & 4.29 \\
Budget records & 4.24 \\
Securities clearing and settlement & 4.23 \\
Contract & 4.15 \\
Settlement and reconciliation of government accounts & 4.14 \\
Automation of budgetary and financial management & 3.96 \\
Inventory control & 3.96 \\
Asset management & 3.94 \\
Public procurement & 3.88 \\
\hline
\end{tabular}

Note. Source: Elaborated by the authors.

Blockchain technology was considered fully applicable in financial transactions by $76.6 \%$ of respondents, and auditing and asset transfer were considered activities where blockchain is fully applicable by $63.3 \%$ and $61.7 \%$ of participants, respectively. Research by Giongo and Balestro (2019) and Biancolini et al. (2018) demonstrated the potential, particularly in banking institutions, of using blockchain in financial transactions and asset transfers. The fact that participants highlighted the activity of auditing is aligned with the findings of Dai and Vasarhelyi (2017) and Bastos et al. (2018).

Virtually all participants (98.9\%) considered there are challenges regarding the use of blockchain in government accounting. The biggest challenges pointed out were lack of knowledge about the technology and its cost-benefit within public agencies, difficulties of implementation in order to replace or adapt traditional systems, and a lack of use cases demonstrating the application of the technology. These results corroborate the findings presented by Giongo and Balestro (2019).

Part of the respondents $(35.1 \%)$ stated that the applicability of blockchain for accounting purposes in their area of work or department is relevant, but it is not a strategic priority. In contrast, $25.5 \%$ of respondents are unsure how their area or department would apply the technology in government accounting. When asked about their perception regarding the intention of the institution or agency they work for to adopt blockchain, 58.7\% of respondents answered negatively. Among the $41.3 \%$ of participants who considered that their agency would 
adopt the technology were the following institutions/agencies: Central Bank of Brazil, IBRD, BNDES, National School of Public Administration - Enap, National Institute of Information Technology, Serpro, and Secretariat of Finance of the states of Rio Grande do Sul and Alagoas and of the Federal District. As shown by Arantes et al. (2018) and Biancolini et al. (2018), BNDES, Central Bank, and Serpro are already developing projects using blockchain technology.

Participants who responded positively cited the following blockchain use cases that the institution may adopt: digital records (30.2\%), auditing (16.3\%), smart contracts (16.3\%), and payments (14\%). The option others included: interbank transfers, registration of transactions in the capital market, traceability, digital cooperatives, and digital identity. Most respondents (89.36\%) believe that blockchain can improve government accounting.

In the content analysis of the three open questions, the data were tabulated and organized into categories (Bardin, 1977), according to the frequency of words (Figure 1). The seven categories of analysis are technology, government accounting, security, transparency, control, change, and knowledge. The analysis of each category is presented below, transcribing some responses identified with $\mathrm{R}$ (respondent) and a number indicating a chronological order of respondents established during the analysis.

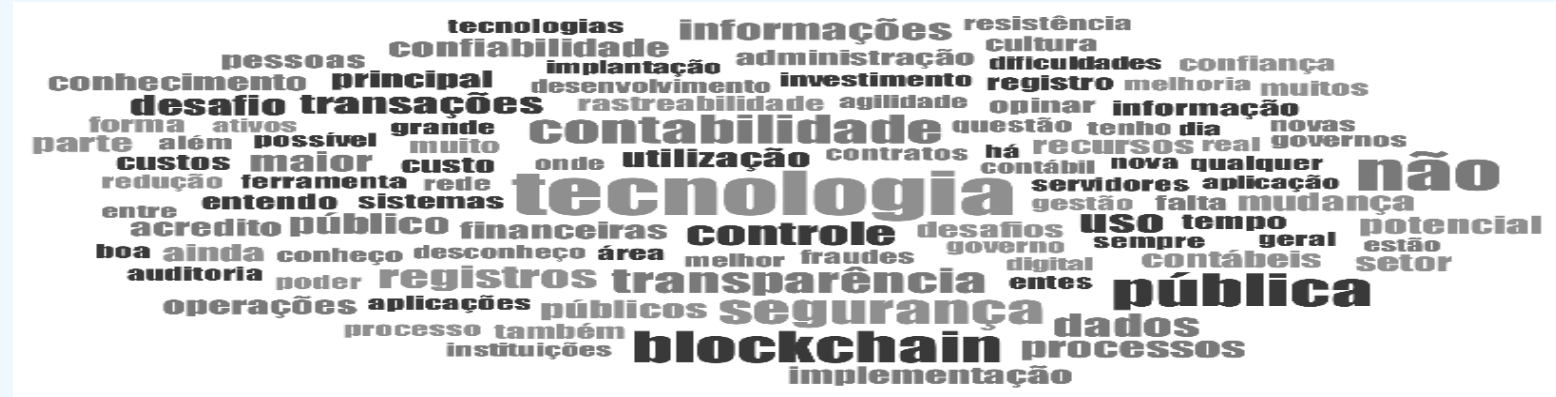

Figure 1. Word cloud.

Elaborated by the authors using the software MAXQDA, based on participants' responses (in Brazilian Portuguese).

For the technology category, the analysis considered technology and blockchain as synonyms. Some respondents identified that this technology can bring improvements to accounting and other areas: "Initially it would be a good idea to use blockchain identities" (R14); "Blockchain is becoming a fundamental tool for the best use of resources and transparency in transactions, with wide application in government" (R2); "Blockchain technology must be applied in the public sector, at several levels, including government accounting processes" (R80).

Most participants considered that technology could help government accounting: "The characteristics of the [blockchain] technology are aligned with the problems of government accounting" (R83). Some respondents cited opportunities such as "the use of new technologies for data control, transparency, and security" (R77), and "technology allows, through validation, increased security of transactions, resulting in reliability and control of public assets" (R92). Some participants are unsure about the topic: "It is a new technology and I still do not understand how it could help government accounting" (R62), "due to the complexity of its implementation, and

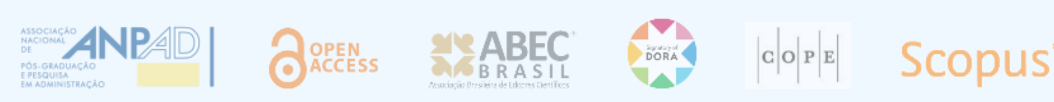


the lack of interest on issues such as control and improvement of public management by part of government officials, who only pursue their own interests" (R89).

The main challenges mentioned about the technology implementation were legal regulation, the lack of trained employees, cultural resistance in the public sector, the "remodeling of processes and systems" (R48), and the "cost of implementation" (R81). Several respondents believe that the technology will be increasingly applied in new use cases: "As occurred with the technology of digital certification, it is first necessary to establish a legal regulation on the technology, then to promote the development of APIs and applications within the scope of public administration" (R41). "There are countless opportunities to use technologies, but it is necessary to start using them in some applications so it is possible to assess the potential and the challenges to be overcome" (R47). "We need to speed this up. Small advances can trigger big ones" (R51).

In addition, cultural issues stood out in the interviews: "The big challenges in adopting blockchain are regulatory bureaucracies and outdated processes. A change of mindset and the modernization of certain processes are necessary, in addition to obtaining support to be able to work on these issues" (R49). In addition, "blockchain is an innovation still poorly understood by the general public. Its implementation would bring an infinite number of benefits, such as those described throughout the research, and would place the development and control of government accounting on another level of efficiency and quality" (R17). Some respondents had a negative view of blockchain: "Blockchain is more like a concept than an actual tool or technology of practical application. It has great potential, but the frontier of its applications is still unknown. It may not even present in practice the full theoretical potential or it may be run over by a breakthrough innovation before it matures" (R63). The excerpt refers to the decentralization of the process, also observed in this answer: "Blockchain technology is no man's land. It is an affront to institutions, and there is no clear, defined responsible body. Who is responsible for the good or bad use of blockchain technology and infrastructure?" (R54). In addition, another respondent cites alternatives: "Blockchain is a decentralized database. There are other models of distributed databases that are simpler and cheaper to maintain” (R39).

Regarding use cases, some participants mentioned transparency for transactions, reduction of failures, security in the information generated, transparency and accountability control, integration, agility, and transfers of resources between agencies. "I believe that the use of smart contracts can lower the cost of public procurement, and blockchain technology can create efficient traceability in government accounting" (R88). "The benefit of blockchain in government accounting is still incipient, but its potential, in relation to data security, costs, and process agility, is valuable for public management" (R1).

In the category government accounting, a large part of the respondents considered that blockchain could help improve activities, particularly offering greater reliability and timeliness in transactions, registers, and information, "real-time accounting" (R79), "giving agility and prompt compliance with accounting demands" (R25). However, not all respondents agree with the technology's capacity to promote improvements, as observed in the following statements: "The challenges of government accounting are not related to technology, but to legal definitions and

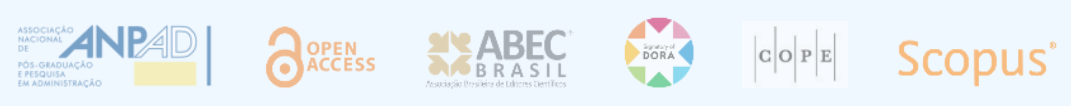


changes that make a comparative analysis between historical series impossible. Today ... it is possible to track the money. The question is whether the public policy was supported; if the needed amount was properly allocated" (R93).

This sentence resorts to one of the characteristics of blockchain (traceability and immutability of records) and, according to Nakamoto (2008), reflects the complexity of government accounting to meet society's needs, including topics such as policy planning and implementation. Blockchain characteristics are also cited in this response: "Transparent, decentralized, immutable, and auditable records are beneficial to government accounting" (R91). Potential use in the area of government accounting was cited, such as "registration of financial assets" (R21), "public procurement" (R32), "compliance, audit, and security" (R57), "accounting with real-time records and validations; transparency of accounts, transactions, and public contracts for the population, transaction reliability, facilitating or even eliminating the need for auditing" (R58).

In terms of challenges, the respondents highlighted "making the XBRL framework compatible, which is the technological challenge legally imposed on national public entities" (R8) and the complexity of implementation: "In the case of the Federal Government, the biggest challenge is the size of this, in order to cover the entire public sector. It demands a lot of IT infrastructure and a lot of related costs" (R18). One of the respondents considered that "it is a great challenge, but it will revolutionize government accounting" (R17).

The category security was related to the security of data, transactions, operations, and information. The respondents mentioned improvements blockchain could bring to government accounting such as "security, reliability, cost reduction with information security, combating fraud" (R68). Among the potential uses, the issue of security was cited in statements such as: "[Blockchain can be used] in financial operations, in areas that require high levels of security for transactions over the web" (R24); "financial transactions would be more efficient and secure" (R46); "I know little, but all critical safety processes can be improved with technology" (R66). Such statements are in line with the analysis of blockchain's potential benefits in public administration. The item information security in Table 5 was significantly highlighted in the analysis.

The category transparency refers to the promotion of transparency of information and processes. Participants mentioned that the technology could contribute by "adding intelligence and facilities to transparency and social participation systems" (R71). "The operating logic of blockchain is horizontal and the creation of information is fully traceable and verifiable as to its origin. In the case of government accounts, it is self-evident that more transparent processes have immediate applicability in the public sector" (R36). In addition, one of the respondents added to this category a possible transition in the work of accountants: "The transparency and trust that blockchain technology brings must transform the day-to-day lives of people who work with accounting, especially government accounting. The level of work should rise dramatically for the tactical and the strategic" (R27). 
As for the category control, some of the respondents pointed out that the control of transactions and data exchanged among public agencies, social accountability, "information control, fraud detection, predictions" (R45) can be improved by the use of blockchain technology in government accounting. Potential uses were "control of budgetary resources" (R67), "internal control" (R22), asset control, "control against fraud and corruption" (R31), and traceability of resources. Among the challenges are asset control, development of new forms of control, and the realization that "improvements in control and process will always face opposition from corrupt people and bureaucrats who gain from the power to create problems to sell solutions. If the process is facilitated, there will be no solution to sell and no bribes to make" (R86). In addition: "The biggest challenge is the managers/power holders who do not want to be controlled by those who finance their activity, that is, taxpayers" (R29).

In this category, it is worth highlighting the direct relationship with the potential benefit listed in Table 5, trust and control. Although the word confiança (trust) was not stressed in Figure 1, this element reflects the fact that blockchain is a distributed database where information is trustworthy, simplifying transactions by removing the intermediary parties. Nakamoto (2008) sought to develop a technology based on cryptographic evidence to promote trust instead of the existence of an intermediary or 'third party trust.' Thus, the technological characteristics of the blockchain (such as cryptographic security and the data distribution structure) can be seen as the trust-building mechanism for transactions, reducing the risk of fraud and increasing data security, as data no longer needs to be provided or managed by centralized entities (Hooper \& Holtbrügge, 2020).

The category change is related to the technology's potential use. According to one of the respondents, blockchain "has the potential to dramatically change the structures of accounting, with numerous gains in efficiency" (R64). Many participants pointed out that the adoption of technology goes through challenges such as "difficulty in the process of change within the public sector" (R12), and "cultural and regulatory barriers" (R42). They understand that blockchain can bring about significant changes in controls and responsibilities, which can block its adoption: "I understand that the problem of adoption is much more cultural than technological. This is because a significant part of public spending in the current model could be exposed, without justification, or definitely attributing blame to the executor, or even hold the manager directly responsible - due to the traceability characteristic, one of the strong characteristics of the technology. I understand this as the main barrier to adoption - unfortunately" (R90). "Although pilot tests are already taking place in the Brazilian public sector, I believe that the main challenge for blockchain is acceptance by the government and employees. It requires a major change of mindset and also investment in training and knowledge on the part of employees" (R2). As already addressed by another respondent, blockchain is seen not just as another technological tool but as a concept that can change processes, dynamics, and power structures in the public sector. This explains why respondents repeatedly mentioned cultural change.

Finally, the category knowledge refers to responses revealing a lack of in-depth knowledge to answer questions about opportunities and challenges of the use of blockchain technology in government accounting. The majority pointed out the importance of greater dissemination,

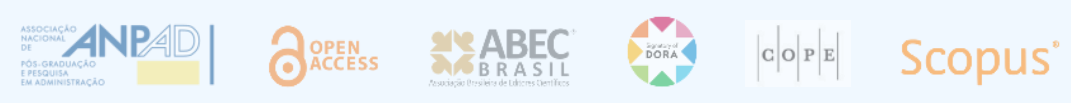


study, benchmarking, and the "need to train employees to seize the opportunities that the technology offers]" (R71). One of the respondents considered that the "greatest challenge will be to overcome ignorance about technology and its cost-benefit within public agencies" (R72).

Thus, the data collected from the open-ended questions suggested that respondents had significant knowledge about the concept and usability of blockchain technology, contrary to the low level of knowledge identified in the study by Migliorini and Rocha (2019). The characteristics of the sample may explain this phenomenon, considering that $48.9 \%$ of the participants in this research are highly qualified and specialized professionals, heavily exposed to information on social media, magazines, and newspapers. In addition, this research corroborates the findings by Giongo and Balestro (2019) who observed that there is still a lack of clarity around the concepts and applications of blockchain technology, and the public sector fails to encourage the use of solutions based on blockchain. In addition, the results reinforce Dai and Vasarhelyi's (2017) finding that professionals need to be trained to better understand and use this technology.

Finally, Table 7 presents the opportunities and challenges listed by the research participants in relation to the seven categories of analysis. This list offers a theoretical consolidation and helps public managers understand the opportunities and challenges of using blockchain technology in public management.

\section{Table 7}

\section{Consolidated of potential uses and challenges by category of analysis}

\begin{tabular}{|c|c|c|}
\hline Category & Potential use & Challenges \\
\hline Technology & $\begin{array}{l}\text { Assistance in public accounting; } \\
\text { control; transparency; security of } \\
\text { public data; facilitated transactions; } \\
\text { reliability; control of public assets }\end{array}$ & $\begin{array}{l}\text { Legal regulation; lack of trained and knowledgeable } \\
\text { civil servants; cultural resistance; cost of } \\
\text { implementation; need to remodel processes and } \\
\text { systems }\end{array}$ \\
\hline $\begin{array}{l}\text { Government } \\
\text { accounting }\end{array}$ & $\begin{array}{l}\text { Greater reliability and timeliness in } \\
\text { transactions, recording data and } \\
\text { information; agility in public accounting }\end{array}$ & $\begin{array}{l}\text { Cultural and procedural challenge of accepting new } \\
\text { processes; new interfaces and procedures due to the } \\
\text { adoption of new technology }\end{array}$ \\
\hline Security & $\begin{array}{l}\text { Data security; secure transactions; } \\
\text { security of operations and information; } \\
\text { assistance in combating fraud }\end{array}$ & $\begin{array}{c}\text { Blockchain technological infrastructure; definition of } \\
\text { network participants and how the information will be } \\
\text { validated }\end{array}$ \\
\hline Transparency & $\begin{array}{l}\text { Greater transparency of information } \\
\text { and public processes }\end{array}$ & $\begin{array}{l}\text { Definition of the most appropriate uses and information } \\
\text { to be disclosed; inform about the channels where to } \\
\text { access information; usability issues }\end{array}$ \\
\hline Control & $\begin{array}{l}\text { Increased social accountability; control } \\
\text { of budgetary resources, fraud, and } \\
\text { corruption; asset control; traceability of } \\
\text { resources }\end{array}$ & $\begin{array}{l}\text { Need for cultural change for active control; } \\
\text { development of new forms of control; resistance to the } \\
\text { implementation of new control mechanisms }\end{array}$ \\
\hline Change & $\begin{array}{l}\text { Substantial modification of existing } \\
\text { public accounting structures, gaining } \\
\text { efficiency; changes in control and } \\
\text { responsibilities }\end{array}$ & $\begin{array}{l}\text { Resistance to novelties arising from changing } \\
\text { processes, dynamics, and structures of power in the } \\
\text { public sector }\end{array}$ \\
\hline Knowledge & $\begin{array}{l}\text { Reliability in the implementation based } \\
\text { on greater disclosure; study and } \\
\text { search for successful cases where the } \\
\text { technology was used }\end{array}$ & $\begin{array}{l}\text { Training and qualification of civil servants in the field; } \\
\text { freedom to use knowledge to implement new solutions }\end{array}$ \\
\hline
\end{tabular}

Note. Source: Elaborated by the authors.

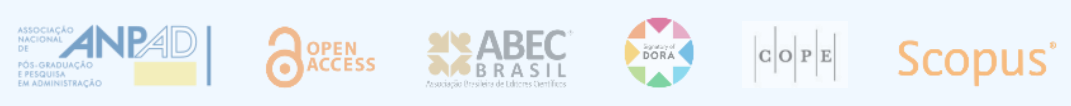




\section{FINAL CONSIDERATIONS}

This study aimed to identify opportunities and challenges of using blockchain technology in government accounting, based on the perception of experts in technology and government accounting. The results demonstrated that professionals were aware of the concept and usability of the technology, which may be explained by the profile of the sample obtained, formed by many highly specialized individuals. The respondents stated they had learned about the topic through many sources such as social media, magazines, documentaries, events, and conversations in the workplace. Most participants considered that blockchain can be applied in financial transactions, auditing, and asset transfers. Among the technology opportunities, the respondents mentioned the elements of trust and control, information security, and control against fraud and corruption. According to the sample, there are challenges to invest in blockchain within government accounting, including the lack of information about the technology and its cost-benefit within public agencies, the challenge to implement systems (by replacing or adapting), and the lack of case uses demonstrating the application of the technology. Regarding the results obtained in the quantitative and qualitative analysis, there is a perception of the opportunities and potential use in the public sector. It is an emerging technology that can generate more transparency, reliability, security, agility in transactions, and optimization of accounting records and processes. Among its main challenges stand out the need for more use cases in the Brazilian public sector, legal regulation, cultural resistance, the lack of knowledge and training for civil servants, the costs of implementation, and the need to remodel processes and systems (Table 7).

The applicability of blockchain technology in government accounting is relevant, but it is not considered a strategic priority. According to the respondents, blockchain use cases in their institution may be related to digital records, auditing, and smart contracts. The study demonstrates that professionals are interested and have expectations regarding technology, considering the improvements it can bring to government accounting. The blockchain technology appeared in 2008. It is still recent and needs to be better understood and more use cases. The importance of expansion in pilot projects and cases is clear, allowing testing the benefits and removing the uncertainties surrounding the technology.

The results presented in this study lead to suggesting partnerships between public agencies and academia in the programs of accounting and technology in order to further examine the topic and develop integrated projects. Also, further studies are crucial, expanding the sample to include other Brazilian states and municipalities. Finally, future research on government accounting should work to verify opportunities and challenges, with a special look at the areas of transactions, auditing, public procurement, and transfer of assets, examining institutions that apply these use cases, describing their path, gains, and losses.

In addition, future studies should look for the reasons for the lack of incentive to find blockchainbased solutions in the public sector, considering the potential benefits of the effective use of this technology. Such investigation could contribute to understand whether technical or political aspects influence decision-making around this issue.

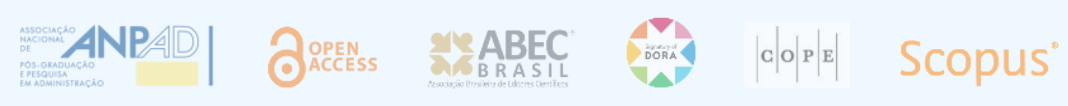




\section{REFERENCES}

Alcantara, L. T. de, Rodrigues, E. A. S., Lima, D. V. de, \& Nunes, A. (2019). Uso da tecnologia Blockchain como instrumento de governança eletrônica no setor público. Trabalhos do Congresso Internacional de Contabilidade Pública, Lisboa, Portugal, 2. Retrieved from https://www.occ.pt/dtrab/trabalhos/iicicp//finais_site/67.pdf

Aquino, M. (2019). Adoção de blockchain na gestão de cadeias de suprimentos do Brasil (Master thesis). Fundação Getulio Vargas, EAESP, São Paulo, SP, Brazil. Retrieved from https://bibliotecadigital.fgv.br/dspace/handle/10438/27321

Arantes, G. M., Jr., D'Almeida, J. N., Jr., Onodera, M. T., Moreno, S. M. B. M., \& Almeida, V. R. S. (2018, May). BNDESToken: Uma proposta para rastrear o caminho de recursos do BNDES. Anais do I Workshop em Blockchain: Teoria, Tecnologias e Aplicações, Porto Alegre, RS, Brazil. Retrieved from https://sol.sbc.org.br/index.php/wblockchain/article/view/2355

Atzori, M. (2015). Blockchain technology and decentralized governance: Is the state still necessary? SSRN. https://dx.doi.org/10.2139/ssrn.2709713

Atzori, M. (2018). Blockchain governance and the role of trust service providers: The TrustedChain ${ }^{\circledR}$ network. The Journal of the British Blockchain Association, 1(1), 55-65. https://doi.org/10.31585/jbba-1-1-(3)2018

Bardin, L. (1977). Análise de conteúdo. Lisboa: Edições 70.

Bastos, P. S. M., Andujar, A. J. F., Rode, F. (2018, September). Os impactos do blockchain na auditoria contábil. Anais do Encontro Catarinense de Estudantes de Ciências Contábeis - ECECON, Florianópolis, SC, Brazil, 16.

Biancolini, A., Silva, F. C. D., Osti, J. R. (2018). Como a tecnologia Blockchain vem impactando ou pode impactar nas estruturas administrativas estatais. Revista Jurídica da Escola Superior de Advocacia da OAB-PR, (8). Retrieved from http://revistajuridica.esa.oabpr.org.br/como-a-tecnologia-blockchain-vem-impactando-ou-pode-impactarnas-estruturas-administrativas-estatais/

Brasil (2017). Matriz de saldos contábeis: Regras gerais e principais observações. Ministério da Fazenda, Secretaria do Tesouro Nacional. $\quad$ Retrieved from http://siconfi.tesouro.gov.br/siconfi/pages/public/arquivo/conteudo/Matriz_de_Saldos_Contabeis_V1_0.pdf

Chahin, A., Cunha, M. A., Knight, P. T., \& Pinto, S. L. (2004). E-gov: A próxima revolução brasileira-eficiência, qualidade e democracia: O governo eletrônico no Brasil e no mundo. São Paulo: Pearson Prentice Hall.

Cohen, B., Amorós, J. E., \& Lundy, L. (2017). The generative potential of emerging technology to support startups and new ecosystems. Business Horizons, 60(6), 741-745. https://doi.org/10.1016/j.bushor.2017.06.004

Colchester, R. (2019, February 19). Mais 6 tendências de blockchain para 2019. Revista CIO. Retrieved from https://cio.com.br/mais-6-tendencias-de-blockchain-para-2019/

Dai, J., \& Vasarhelyi, M. (2017). Toward blockchain-based accounting and assurance. Journal of Information Systems, 31(3), 5-21. https://doi.org/10.2308/isys-51804

Darlington, N. (2021, September 22). Blockchain for beginners: What is blockchain technology? A Step-by-step guide. Blockgeeks. Retrieved from https://blockgeeks.com/guides/what-is-blockchain-technology/

Formigoni, J. R., Filho, Braga, A. M., \& Leal, R. L. V. (2017). Tecnologia blockchain: Uma visão geral [White paper]. Retrieved from https://www.cpqd.com.br/wp-content/uploads/2017/03/cpqd-whitepaper-blockchainimpresso.pdf

Gil, A. C. (2008). Métodos e técnicas de pesquisa social (6 ed). São Paulo: Atlas.

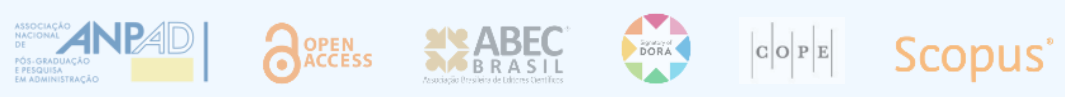


Giongo, J., \& Balestro, G. (2019, August). Os impactos da utilização da tecnologia blockchain para a área contábil e financeira. Anais da Convenção de Contabilidade do Rio Grande do Sul, Bento Gonçalves, RS, Brazil, 17. Retrieved from http://www.crcrs.org.br/convencao/trabalhos/12_914_impactos_utilizacao_tecnologia_blockhain.pdf

Hooper, A., \& Holtbrügge, D. (2020). Blockchain technology in international business: Changing the agenda for global governance. Review of International Business and Strategy, 30(2), 183-200. https://doi.org/10.1108/RIBS06-2019-0078

Ionescu, L. (2019). Big data, blockchain, and artificial intelligence in cloud-based accounting information systems. Analysis and Metaphysics, (18), 44-49. https://doi.org/10.22381/AM1820196

Kossow, N., \& Dykes, V. (2018). Embracing digitalisation: How to use ICT to strengthen anti-corruption. GIZ. Retrieved from https://www.giz.de/de/downloads/giz2018-eng_ICT-to-strengthen-Anti-Corruption.pdf

Lee, C. S., \& Tajudeen, F. P. (2020). Usage and impact of artificial intelligence on accounting: Evidence from Malaysian organizations. Asian Journal of Business and Accounting, 13(1). https://doi.org/10.22452/ajba.vol13no1.8

Melati, C., \& Janissek-Muniz, R. (2020). Smart government: Analysis of dimensions from the perspective of public managers. Revista de Administração Pública, 54(3), 400-415. https://doi.org/10.1590/0034-761220190226

Migliorini, I. B, \& Rocha, E. (2019). Estudo de viabilidade sobre a utilização do blockchain na contabilidade. CAFI - Contabilidade, Atuária, Finanças E̊ Informação, 2(1), 99-111. https://doi.org/10.23925/cafi.v2i1.40601

Moura, L. M. F. de, Brauner, D. F., \& Janissek-Muniz, R. (2020). Blockchain and a technological perspective for public administration: A systematic review. Revista de Administração Contemporânea, 24(3), 259-274. https://doi.org/10.1590/1982-7849rac2020190171

Nakamoto, S. (2008). Bitcoin: A peer-to-peer electronic cash system [White Paper]. Retrieved from https://bitcoin.org/bitcoin.pdf

Nofer, M., Gomber, P., Hinz, O., \& Schiereck, D. (2017). Blockchain. Business Eु Information Systems Engineering, 59(3), 183-187. https://doi.org/10.1007/s12599-017-0467-3

Pimenta, C., \& Seco, A. (2019). Oportunidades tecnológicas y recomendaciones para la modernización de los sistemas integrados de administración financiera en América Latina y el Caribe [Documento para Discusión $n^{\circ}$ IDB-DP-651]. Sector de Instituciones para el Desarrollo, División de Gestión Fiscal, Banco Interamericano de Desarrollo. Retrieved

from https://publications.iadb.org/publications/spanish/document/Oportunidades_tecnol\%C3\%B3gicas_y_recom endaciones_para_la_modernizaci\%C3\%B3n_de_los_sistemas_integrados_de_administraci\%C3\%B3n_financi era_en_Am\%C3\%A9rica_Latina_y_el_Caribe.pdf

Rikhardsson, P., \& Yigitbasioglu, O. (2018). Business intelligence \& analytics in management accounting research: Status and future focus. International Journal of Accounting Information Systems, 29, 37-58. https://doi.org/10.1016/j.accinf.2018.03.001

Scholl, H. J., \& Bolivar, M. P. R. (2019). Regulation as both enabler of technology use and global competitive tool: The Gibraltar case. Government Information Quarterly, 36(3), 601-613. https://doi.org/10.1016/j.giq.2019.05.003

Schwab, K. (2016). A quarta revolução industrial. São Paulo: Edipro.

Sebold, M., Pioner, L., Schappo, C., Pioner, J. J. (2012). Evolução da contabilidade brasileira: Do governo eletrônico ao sistema público de escrituração digital - SPED. Enfoque: Reflexão Contábil, 31(2), 23-32. Retrieved from http://www.redalyc.org/articulo.oa?id=307124727003

Swan, M. (2015). Blockchain: Blueprint for a new economy. Boston: O’Reilly Media.

Talwar, R. (2015). The future of business: Critical insights into a rapidly changing world from 60 future thinkers (1 ed). London: Fast Future Publishing.

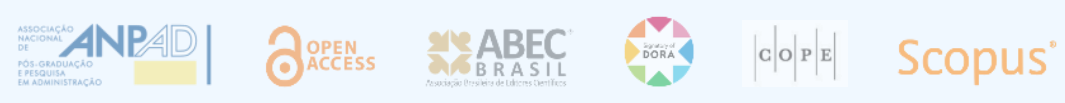


Tapscott, D., \& Tapscott, A. (2016). Blockchain revolution: How the technology behind bitcoin is changing money, business, and the world. London: Portfolio.

Thakur, V., Doja, M. N., Dwivedi, Y. K., Ahmad, T., \& Khadanga, G. (2019). Land records on blockchain for implementation of land titling in India. International Journal of Information Management, 52, 101940. https://doi.org/10.1016/j.ijinfomgt.2019.04.013

Wright, A., \& Filippi, P. D. (2015). Decentralized blockchain technology and the rise of lex cryptographia. SSRN. https://doi.org/10.2139/ssrn.2580664

Xu, X., Weber, I., Staples, M. (2019) Case study: OriginChain. In Architecture for blockchain applications (pp. 279-293). Cham: Springer. https://doi.org/10.1007/978-3-030-03035-3_14

Yermack, D. (2017). Corporate governance and blockchains. Review of Finance, 21(1), 7-31. https://doi.org/10.1093/rof/rfw074

Zachariadis, M., Hileman, G., \& Scott, S. V. (2019). Governance and control in distributed ledgers: Understanding the challenges facing blockchain technology in financial services. Information and Organization, 29(2), 105-117. https://doi.org/10.1016/j.infoandorg.2019.03.001 


\section{Authors' contributions}

$\mathbf{1}^{\text {st }}$ author: conceptualization (lead), data curation (lead), formal analysis (lead), investigation (lead), methodology (lead), project administration (lead).

$2^{\text {nd }}$ author: conceptualization (equal), data curation (supporting), formal analysis (equal), investigation (supporting), methodology (equal), project administration (supporting).

$3^{\text {rd }}$ author: conceptualization (supporting), data curation (supporting), formal analysis (equal), investigation (supporting), methodology (equal), project administration (supporting).

\section{Authors}

\section{Paula Raymundo Prux}

Universidade Federal do Rio Grande do Sul, Escola de Administração

Av. João Pessoa, 52, Centro, 90040-000, Porto Alegre, Rio Grande do Sul, Brazil paulaprux@gmail.com

(iD) https://orcid.org/0000-0003-0251-7014

\section{Fernanda da Silva Momo}

Universidade Federal do Rio Grande do Sul, Faculdade de Ciências Econômicas Av. João Pessoa, 52, Centro, 90040-000, Porto Alegre, Rio Grande do Sul, Brazil fernandamomo@yahoo.com.br

(iD) https://orcid.org/0000-0002-6512-5280

\section{Claudia Melati*}

Universidade Federal do Rio Grande do Sul, Escola de Administração Av. João Pessoa, 52, Centro, 90040-000, Porto Alegre, Rio Grande do Sul, Brazil cmelati@yahoo.com.br

iD https://orcid.org/0000-0002-9369-0113

* Corresponding author

Peer review is responsible for acknowledging an article's potential contribution to the frontiers of scholarly knowledge on business or public administration. The authors are the ultimate responsible for the consistency of the theoretical references, the accurate report of empirical data, the personal perspectives, and the use of copyrighted material.

This content was evaluated using the double-blind peer review process. The disclosure of the reviewers' information on the first page is made only after concluding the evaluation process, and with the voluntary consent of the respective reviewers. 


\section{APPENDIX A - QUESTIONNAIRE}

Opportunities and challenges of using blockchain technology in government accounting in Brazil

\section{IDENTIFICATION}

\section{Gender:}

( ) Female

() Male

2. Age:

3. Institution where you work:

\section{Profession:}

\section{Academic education:}

( ) Business

( ) Accounting

( ) Legal and Social Sciences/Law

( ) Information and Communication Technology

( ) Other

\section{Education level:}

( ) Technician

( ) University graduate

( ) Postgraduate studies

() Master's degree

( ) Doctorate degree

\section{How do you describe your knowledge about blockchain technology?}

( ) I've heard the term, but I can't define blockchain

( ) I can define blockchain, but I am not aware of the applicability

( ) I can define blockchain, I am aware of the applicability in general, but I cannot see usability yet

( ) I can define blockchain, I can see the usability, but I don't participate in projects in the area

( ) I can define blockchain, I am aware of the applicability, and I participate or I have already participated in a study or application project involving the theme

8. The source of your level of knowledge about blockchain technology comes from (you can check more than one alternative):

Academic articles

Courses

Media (social networks, magazines, newspapers...)

$\square$ Speeches

Projects and/or work meetings

Others

If you have marked 'others,' please describe where you learned about blockchain technology: 
9. In your opinion, what potential benefits can be derived from the use of blockchain technology in public accounting?

\begin{tabular}{|c|c|c|c|c|c|}
\hline & $\begin{array}{c}\text { Not } \\
\text { applicable }\end{array}$ & $\begin{array}{l}\text { Applies } \\
\text { little }\end{array}$ & Indifferent & Applies partially & Applies fully \\
\hline $\begin{array}{l}\text { Access to information and } \\
\text { transparency }\end{array}$ & ( ) & ( ) & ( ) & ( ) & ( ) \\
\hline Predictive data capacity & ( ) & ( ) & ( ) & ( ) & ( ) \\
\hline Trust and control & ( ) & ( ) & ( ) & ( ) & ( ) \\
\hline $\begin{array}{l}\text { Control against fraud and } \\
\text { corruption }\end{array}$ & ( ) & ( ) & ( ) & ( ) & ( ) \\
\hline Efficiency & ( ) & ( ) & ( ) & ( ) & ( ) \\
\hline Governance & ( ) & ( ) & ( ) & ( ) & ( ) \\
\hline Data quality & ( ) & ( ) & () & ( ) & () \\
\hline Information security & ( ) & ( ) & ( ) & ( ) & ( ) \\
\hline
\end{tabular}

10. For you, can blockchain be applied in the following activities related to public accounting?

\begin{tabular}{|c|c|c|c|c|c|}
\hline & $\begin{array}{c}\text { Not } \\
\text { applicable }\end{array}$ & $\begin{array}{l}\text { Applies } \\
\text { little }\end{array}$ & Indifferent & Applies partially & Applies fully \\
\hline Audit & ( ) & ( ) & ( ) & ( ) & ( ) \\
\hline $\begin{array}{l}\text { Improvement of inspection } \\
\text { capacity and tax collection }\end{array}$ & ( ) & () & ( ) & ( ) & ( ) \\
\hline $\begin{array}{l}\text { Automation of budgetary and } \\
\text { financial management }\end{array}$ & ( ) & ( ) & ( ) & ( ) & ( ) \\
\hline $\begin{array}{l}\text { Clearing and settlement of } \\
\text { securities }\end{array}$ & ( ) & ( ) & ( ) & ( ) & ( ) \\
\hline Compliance & ( ) & ( ) & ( ) & ( ) & ( ) \\
\hline $\begin{array}{l}\text { Settlement and reconciliation of } \\
\text { government accounts }\end{array}$ & ( ) & ( ) & ( ) & ( ) & ( ) \\
\hline Contracts & ( ) & ( ) & ( ) & ( ) & ( ) \\
\hline Warehouse/inventory control & ( ) & () & ( ) & ( ) & () \\
\hline Wealth management & ( ) & ( ) & ( ) & ( ) & () \\
\hline Publications & ( ) & ( ) & ( ) & ( ) & () \\
\hline Accounting records & ( ) & ( ) & ( ) & ( ) & ( ) \\
\hline Budget records & ( ) & ( ) & ( ) & ( ) & ( ) \\
\hline
\end{tabular}




\begin{tabular}{|l|c|c|c|c|} 
Financial transactions & $($ ) & $($ ) & ( ) & ( ) \\
\hline Asset transfer & $($ ) & $($ ) & ( ) & ( ) \\
\hline
\end{tabular}

11. Do you think there are challenges to investing in blockchain technology within public accounting?

( ) Yes
( ) No

12. If you answered yes to the previous question, check what are the biggest challenges to invest in blockchain technology within public accounting, in your opinion (you can check more than one alternative):

$\square$ High infrastructure costs for implementation (such as electricity costs)

$\square$ Lack of knowledge about technology and its cost-benefit within public agencies

$\square$ Missing use cases and technology applications

$\square$ Implementation/difficulties in replacing or adapting systems

$\square$ Scalability/performance concerns

$\square$ Security concerns

$\square$ Regulatory issues

$\square$ Reluctance to change established processes

$\square$ Not a priority at the moment

$\square$ There are no challenges

13. How do you perceive that your industry sees the applicability of blockchain for accounting purposes?

( ) It is not and will not be relevant

( ) Relevant, but not a strategic priority

( ) Important, but not part of the Top 5 strategic priorities

( ) Critical, part of the Top 5 strategic priorities

( ) I am not sure

14. There is an intention of the institution where you work to adopt blockchain technology?

() Yes

( ) No

15. If so, please describe which of the following blockchain use cases your institution may adopt:

( ) Digital records

( ) Internet of things (IoT)

( ) Payments

( ) Audit

( ) Smart contracts

( ) Others

If you checked 'others,' describe which blockchain use cases the institution may adopt: 
16. For you, blockchain technology can bring improvements to public accounting?

() Yes

( ) No

17. Justify your answer:

18. Give your opinion on the POTENTIALS OF USE of blockchain technology in public accounting:

19. Give your opinion on the CHALLENGES of blockchain technology in public accounting: 